\title{
KEBIJAKAN INTERNAL MADRASAH \\ DALAM MEMENUHI KEPUASAN ORANG TUA \\ SISWA DI MADRASAH IBTIDAIYAH NEGERI 1 \\ KULON PROGO
}

Sudarman

MIN 2 Kulon Progo, Wates, Kulonprogo, Daerah Istimewa Yogyakarta

Email: paksudarman1970@gmail.com

\begin{abstract}
ABSTRAK
Tujuan dari penelitian ini adalah mendeskripsikan kebijakan internal di MIN 1 Kulonprogo dalam memenuhi kepuasan orang tua siswa. Penelitian ini menggunakan pendekatan kualitatif dengan metode studi kasus. Data dikumpulkan dengan wawancara mendalam, observasi, dan dokumentasi. Hasil penelitian ini menunjukkan bahwa MIN 1 Kulonprogo mengupayakan 5 kebijakan untuk memenuhi harapan orang tua siswa, yaitu: kebijakan peningkatan kualitas ibadah siswa, kebijakan peningkatan akhlak dan budi pekerti siswa, kebijakan peningkatan keterampilan siswa, kebijakan peningkatan prestasi belajar, dan kebijakan peningkatan prestasi akademik dan non akademik siswa. Melalui kebijakan-kebijakan tersebut harapan-harapan orang tua siswa terpenuhi. Orang tua siswa pun merasa puas dengan kinerja madrasah, citra madrasah meningkat, kepercayaan masyarakat terhadap madrasah bertambah, salah satunya terlihat dari membludaknya jumlah penerimaan siswa baru.
\end{abstract}

Kata Kunci: Harapan Orang tua, Kebijakan Internal Madrasah, Kepuasan Orang tua.

\section{ABSTRACT}

The purpose of this study was to describe the internal policy at State Madrasah Ibtidaiyah (Islamic State Elementary School) of Kulonprogo 1 in meeting the parents' satisfaction. This study uses a qualitative approach with a case study method. Data was collected 
by in-depth interviews, observations, and documentation. The results of this study indicate that SMI of Kulonprogo 1 seeks 5 policies to meet the expectations of parents of students, namely: policies to improve the quality of student worship, policies to improve morals and character of students, policies to improve student skills, policies to improve learning achievement, and policies on improving academic achievement and non academic students. Through these policies parents' expectations are met. The parents of the students were satisfied with the performance of the madrasa, the image of the madrasa increased, public trust in the madrasa increased, one of which was seen from the large number of new student admissions.

Keywords: Parents' Expectation, Madrasah's Internal Policies, Parents' Satisfaction

\section{A. PENDAHULUAN}

Pada era globalisasi seperti sekarang ini pendidikan merupakan suatu kegiatan yang sangat dibutuhkan oleh manusia seiring dengan kemajuan ilmu pengetahuan dan teknologi yang berkembang dengan pesat. Pendidikan tidak hanya sebagai usaha pemberian informasi pengetahuan serta keterampilan saja namun pendidikan juga harus dapat mewujudkan keinginan dan kebutuhan manusia. Dalam dunia modern seperti sekarang, pendidikan juga harus dapat menjadikan tonggak penanaman nilai-nilai sosial dan budi pekerti pada peserta didik. Kepribadian mencakup berbagai aspek dan sifat-sifat fisik maupun psikis dari setiap individu. ${ }^{1}$

Pendidikan nilai bukan sekadar proses penanaman nilai moral untuk membentengi diri dari akses negatif globalisasi. Hal yang terpenting adalah bagaimana nilai moral yang telah ditanamkan pendidikan nilai mampu membebaskan dari kebodohan dan

${ }^{1}$ Ngalim Purwanto, Psikologi Pendidikan (Bandung: PT. Remaja Rosdakarya, 2007), hlm. 155. 
keterbelakangan. ${ }^{2}$ Di samping itu, pendidikan karakter sangat penting ditanamkan pada peserta didik. Dengan pendidikan karakter, dapat membentuk peserta didik yang memiliki jiwa kebangsaan yang tangguh, kompetitif, berakhlak mulia, bermoral, bertoleransi, bergotong-royong, berjiwa patriotik, berkembang dinamis, berorientasi pada ilmu pengetahuan dan teknologi yang dijiwai Pancasila, iman dan takwa kepada Tuhan Yang Maha Esa. ${ }^{3}$

Madrasah merupakan lembaga pendidikan yang berada di bawah binaan Kementerian Agama dan merupakan salah satu dari lembaga pendidikan yang berada di masyarakat dan berkembang di seluruh pelosok tanah air. Maksud didirikannya madrasah adalah untuk memenuhi kebutuhan masyarakat, bahwa mereka ingin memiliki generasi yang memiliki bekal agama yang kuat serta memiliki pengetahuan yang tidak kalah dengan siswa yang sekolah di sekolah umum (SD). Sehingga mereka ingin menyatukan antara kelebihan agama yang diperoleh di pesantren dengan pengetahuan umum yang diperoleh di sekolah dasar menjadi satu lembaga yaitu madrasah ibtidaiyah. Madrasah dan masyarakat memiliki hubungan yang sangat erat dalam mencapai tujuan madrasah atau pendidikan secara efektif dan efisien, madrasah harus menunjang pencapaian tujuan atau pemenuhan kebutuhan masyarakat, khususnya kebutuhan pendidikan, madrasah harus mengetahui kebutuhan,

${ }^{2}$ Qiqi Yuliati Zakiah and A Rusdiana, Pendidikan Nilai Kajian Teori dan Praktik di Sekolah (Bandung: Pustaka Setia, 2014), hlm. 131.

3 Pemerintah Daerah Kulon Progo, Buku Pedoman Pelaksanaan Pendidikan Karakter Kabupaten Kulon Progo Jenjang SD/MI, 2017, hlm. 7. 
harapan, dan tuntutan masyarakat. ${ }^{4}$ Kepala madrasah harus mampu memenuhi permintaan konsumen dalam hal ini adalah siswa dan orang tua / wali siswa sebagai stakeholder dalam sebuah lembaga pendidikan. $^{5}$

Masyarakat ingin memiliki generasi Islam yang tangguh dan mampu berkompetisi dalam era sekarang ini, sehingga juga mampu menjadi pemeran utama dalam dunia kerja yang tetap berlandaskan ajaran-ajaran agama, bukan malah sebaliknya hanya menjadi generasi penonton yang menjadi obyek orang lain. Fenomena yang terjadi dalam masyarakat, tidaklah seperti yang diharapkan. Hal ini terjadi karena, sebagian madrasah belum bisa memenuhi harapan pelanggan pendidikan, banyak madrasah yang belum mampu bersaing dengan sekolah umum dalam mengembangkan mutu pendidikan, bahkan kenyataannya di beberapa daerah nilai hasil ujian sekolah/madrasah untuk tingkat madrasah ibtidaiyah masih banyak yang rangkingnya berada di level bawah pada tingkat kecamatan. Hal ini menjadikan madrasah kurang diminati masyarakat, kenyataannya bahwa pada saat penerimaan peserta didik baru sebagian masyarakat justru memilih memasukkan putraputrinya di sekolah umum dan madrasah menjadi pilihan kedua, mereka masuk madrasah setelah tidak diterima di sekolah umum.

4 Mulyasa, Pedoman Manajemen Berbasis Madrasah (Jakarta: Direktorat Jenderal Kelembagaan Agama Islam DEPAG RI, 2004), hlm. 67.

${ }^{5}$ Nurul Mufidah, "Peran Manajer Kepala MIN Jejeran Bantul Dalam Implementasi Manajemen Berbasis Madrasah," Jurnal Manajemen Pendidikan Islam 2, no. 1 (2007), hlm. 46. 
Hal ini terjadi karena madrasah belum mampu memenuhi kepuasan orang tua siswa sebagai pelanggan pendidikan. Di samping itu, berdirinya sekolah baru serta terjadinya persaingan antar sekolah untuk meningkatkan pelayanan mutu pendidikan menyebabkan orang tua sebagai pelanggan pendidikan lebih memilih sekolah umum dari pada madrasah. Untuk ini, kebijakan kepala madrasah mempunyai peranan penting dalam meningkatkan kinerja stakeholder yang ada, termasuk komite madrasah harus tahu dan memahami tentang persepsi tersebut dan mengetahui keinginan masyarakat terhadap madrasah, mengapa mereka kurang termotivasi untuk masuk madrasah.

Realitas seperti sekarang ini tidak boleh dibiarkan dan harus segera diindentifikasi penyebabnya dan dicari solusinya. Kepuasan orang tua siswa mempunyai peranan penting dalam menentukan kelangsungan madrasah agar tetap eksis di masyarakat. Pelanggan haruslah merupakan prioritas utama organisasi. Kelangsungan organisasi tergantung pada pelanggan. ${ }^{6}$ Dengan demikian, diperlukan upaya-upaya untuk merubah persepsi masyarakat serta menumbuhkan kembali motivasinya.

Madrasah Ibtidaiyah Negeri 1 Kulonprogo yang dulu bernama Madrasah Ibtidaiyah Negeri Sindutan merupakan madrasah yang telah memiliki banyak prestasi baik dalam akademik maupun non akademik, walaupun dalam prestasi akademik belum mampu menduduki rangking pertama di tingkat kecamatan, namun pernah masuk pada lima besar, di samping itu juga dengan prestasi non

${ }^{6}$ Fandy Tjiptono and Anastasia Diana, Total Quality Management (Yogyakarta: Andi Offset, 2003), hlm. 102. 
akademik yang lain yang pernah menduduki sebagai madrasah teladan nasional. Dalam perkembangannya seiring banyaknya keinginan orang tua yang ingin menyekolahkan anak-anaknya di MIN Sindutan maka madrasah ini kemudian menambah jumlah rombel dengan mengajukan surat permohonan penambahan rombel ke Kantor Wilayah Kementerian Agama Daerah Istimewa Yogyakarta, sehingga mulai tahun pelajaran 2010/2011 madrasah mulai menerima 2 kelas untuk kelas satu. ${ }^{7}$

\section{B. METODE PENELITIAN}

Penelitian ini menggunakan pendekatan kualitatif. Metode penelitian kualitatif adalah metode penelitian yang berlandaskan pada filsafat post-positivisme, digunakan untuk meneliti pada kondisi obyek yang alamiah di mana peneliti adalah sebagai instrumen kunci, pengambilan sampel sumber data dilakukan dilakukan secara purposive dan snowball, teknik pengumpulan data dengan triangulasi, analisis data bersifat induktif/kualitatif, dan hasil penelitian kualitatif lebih menekankan makna daripada generalisasi. ${ }^{8}$

Teknik pengumpulan data yang digunakan dalam penelitian ini adalah observasi, wawancara, dan dokumentasi. Subjek penelitian yang dipilih peneliti dengan menggunakan purposive sampling yaitu kepala madrasah, guru dan orang tua siswa dan

${ }^{7}$ Wawancara dengan Widodo, S.Pd.I kepala MIN 1 Kulon Progo, dan dokumentasi MIN 1 Kulon Progo, pada tanggal 15 Agustus 2018.

${ }^{8}$ Sugiyono Sugiyono, Metode Penelitian Pendidikan: Pendekatan Kuantitatif, Kualitatif dan R\&D (Bandung: Alfabeta, 2010), hlm. 15. 
komite MIN 1 Kulon Progo. Tahapan dalam analisis data yaitu reduksi data, penyajian data dan penarikan kesimpulan.

\section{HASIL PENELITIAN DAN PEMBAHASAN}

\section{Kepuasan Orang Tua Siswa Terhadap Layanan}

\section{Pendidikan di Madrasah Ibtidaiyah Negeri 1 Kulon Progo}

Kepuasan orang tua siswa terhadap pelayanan pendidikan di MIN 1 Kulon Progo dapat ditunjukan melalui keselarasan antara harapan orang tua dengan kinerja madrasah. Penjelasan selengkapnya dapat diuraikan sebagai berikut :

a. Kepuasan Orang Tua Terhadap Peningkatan Ibadah Siswa

Harapan orang tua siswa terhadap peningkatan ibadah siswa di MIN 1 Kulon Progo meliputi: siswa dapat melaksanakan ibadah dengan baik dan benar sesuai syariat agama Islam, terbiasa melakukan ibadah dengan mempunyai kesadaran sendiri tanpa harus mendapat tekanan dari orang lain. Sehingga nantinya menjadi anak yang sholeh dan sholehah.

Penjelasan di atas sesuai dengan penuturan Agus Riyanto yang menyatakan bahwa sebagai orang tua berharap agar anak dapat melaksanakan ibadah dengan baik dan benar sesuai syariat agama Islam. ${ }^{9}$ Sedangkan menurut Dwi Maryanti, menyampaikan sebagai orang tua berharap agar anak terbiasa melakukan ibadah dengan mempunyai kesadaran sendiri tanpa harus diperintah orang tua. Sehingga nantinya menjadi anak

9 Wawancara dengan Bapak Agus Riyanto orang tua dari Ahmad Musthofa Habibulloh kelas IV

A, tanggal 9 September 2018. 
yang sholeh dan sholehah. ${ }^{10}$ Lain lagi dengan Nur Rohmah, yang menuturkan orang tua berharap agar anak dapat melaksanakan shalat dengan benar, senang mengaji, dapat membaca Qur'an, dan menjadi anak yang bertakwa serta sholehah. ${ }^{11}$

Sementara itu, kinerja madrasah dalam peningkatan ibadah siswa dapat ditunjukkan melalui berbagai kegiatan yaitu; kegiatan shalat Zuhur berjamaah, kegiatan shalat Dhuha, tadarus dan hafalan Juz 'Amma, pembelajaran tahfidz, serta membaca dan hafalan Asmaul Husna.

Kegiatan peningkatan ibadah siswa di MIN 1 Kulon Progo dilaksanakan mulai semester satu tahun pelajaran 2017/2018 dengan diterbitkannya surat keputusan kepala MIN 1 Kulon Progo Nomor 15 tahun 2017 tentang Penyelenggaraan Kegiatan Pembiasaan di madrasah.

Menurut Kotler, kepuasan pelanggan adalah tingkat perasaan seseorang setelah membandingkan kinerja (atau hasil) yang ia rasakan dibandingkan dengan harapannya. ${ }^{12}$

Berdasarkan uraian di atas dapat ditarik kesimpulan bahwa kinerja MIN 1 Kulon Progo dalam peningkatan ibadah siswa yang meliputi; shalat Zuhur berjamaah, kegiatan shalat Dhuha, tadarus dan hafalan Juz 'Amma, pembelajaran tahfidz,

${ }^{10}$ Wawancara dengan Ibu Dwi Maryanti orang tua dari Abrisyam Arya Ramadhan kelas V A, 9 September 2018.

${ }^{11}$ Wawancara dengan Ibu Nur Rohmah orang tua dari Alya Hanafi kelas 1 A, 9 September 2018.

${ }^{12}$ Fandy Tjiptono, Manajemen Jasa, 4th ed. (Yogyakarta: Andi Offset, 2006), hlm. 146-147. 
serta membaca dan hafalan Asmaul Husna. Sejalan dengan harapan orang tua yang meliputi; anak dapat melaksanakan ibadah dengan baik dan benar sesuai syariat agama Islam, terbiasa melakukan ibadah dengan mempunyai kesadaran sendiri tanpa harus diperintah orang tua, menjadi anak yang sholeh dan sholehah, dapat melaksanakan sholat dengan benar, senang mengaji, dapat membaca Qur'an, dan menjadi anak yang bertakwa.

b. Kepuasan Orang Tua terhadap Peningkatan Akhlak dan Kepribadian Siswa

Harapan orang tua siswa terhadap peningkatan akhlak dan kepribadian siswa adalah siswa mempunyai akhlak yang baik (berakhlakul karimah), berlaku sopan dan memiliki tata krama dalam pergaulan baik kepada guru, orang tua, maupun dalam pergaulan di masyarakat. Dapat memilih teman dan bergaul dengan mengedepankan akhlak terpuji.

Sedangkan harapan orang tua terhadap peningkatan akhlak dan kepribadian siswa meliputi; anak memiliki akhlak terpuji, tata krama dalam pergaulan, menghormati orang tua, memiliki kepribadian yang baik, berlaku sopan. ${ }^{13}$ Sementara itu, kinerja madrasah dalam peningkatan akhlak dan kepribadian siswa dapat ditunjukan melalui kegiatan mengucapkan salam dan berjabat tangan serta mencium tangan guru setiap pagi, berjabat tangan antar siswa dalam satu kelas setiap pagi, bertutur

13 Rangkuman wawancara dengan orang tua siswa, Agus Riyanto, Dwi Maryanti, dan Nur Rohmah, 9 September 2018 
kata sopan dengan bahasa Jawa, berjabat tangan kepada seluruh siswa saat selesai upacara.

Menurut. Kotler, kepuasan pelanggan adalah tingkat perasaan seseorang setelah membandingkan kinerja (atau hasil) yang ia rasakan dibandingkan dengan harapannya. ${ }^{14}$ Berdasarkan uraian di atas dapat ditarik kesimpulan bahwa kinerja MIN 1 Kulon Progo dalam peningkatan akhlak dan kepribadian siswa meliputi; mengucapkan salam dan berjabat tangan serta mencium tangan guru setiap pagi, berjabat tangan antar siswa dalam satu kelas setiap pagi saat tiba di madrasah, bertutur kata sopan dengan bahasa jawa, setiap hari Sabtu dengan pengantar bahasa Jawa, berjabat tangan kepada seluruh siswa saat selesai upacara. Hal tersebut sejalan dengan harapan orang tua yaitu; anak memiliki akhlak terpuji, tata krama dalam pergaulan, menghormati orang tua, memiliki kepribadian yang baik, dan berlaku sopan.

c. Kepuasan Orang Tua terhadap Peningkatan Keterampilan Siswa Harapan orang tua terhadap peningkatan keterampilan siswa meliputi; anak memiliki keterampilan yang dapat menjadi bekal hidupnya, memiliki bermacam-macam keterampilan, memiliki keterampilan yang berguna dalam kehidupannya di masyarakat misalnya baca seni Al-Qur'an. ${ }^{15}$ Sementara itu, kinerja madrasah dalam peningkatan keterampilan siswa dapat

\footnotetext{
14 Tjiptono, Manajemen Jasa..., hlm. 146-147.

15 Rangkuman wawancara dengan orang tua siswa, Agus Riyanto, Dwi Maryanti, dan Nur Rohmah, 9 September 2018.
} 
ditunjukan melalui kegiatan kepramukaan, qosidah, musik, hadroh, qiroah, drumband dan kempo.

Hal tersebut sesuai dengan penjelasan kepala madrasah, kegiatan di MIN 1 Kulon Progo dalam peningkatan keterampilan siswa yaitu kegiatan Kepramukaan, kegiatan qosidah, kegiatan musik, kegiatan hadroh, kegiatan qiroah, kegiatan drumband, dan kegiatan kempo. ${ }^{16}$

Menurut Kotler, kepuasan pelanggan adalah tingkat perasaan seseorang setelah membandingkan kinerja (atau hasil) yang ia rasakan dibandingkan dengan harapannya. ${ }^{17}$ Berdasarkan uraian di atas dapat ditarik kesimpulan bahwa kinerja MIN 1 Kulon Progo dalam peningkatan keterampilan siswa yang meliputi; kegiatan kepramukaan, qosidah, musik, hadroh, qiroah, drumband dan kempo sejalan dengan harapan orang tua siswa yaitu; anak memiliki keterampilan yang dapat menjadi bekal hidupnya, memiliki bermacam-macam keterampilan, memiliki keterampilan yang berguna dalam kehidupannya di masyarakat misalnya baca seni Al-Qur'an.

d. Kepuasan Orang Tua terhadap Nilai Ulangan Siswa

Harapan orang tua terhadap nilai ulangan siswa yaitu siswa memiliki kecerdasan intelektual yang tinggi, sehingga nilai ulangannya di atas nilai Kriteria Ketuntasan Minimal (KKM), karena di MIN 1 Kulon Progo proses pembelajaran dengan didukung berbagai fasilitas yang memadai. Penjelasan

${ }^{16}$ Wawancara dengan Kepala MIN 1 Kulon Progo, Widodo, S.Pd.I, 13 September 2018.

17 Tjiptono, Manajemen Jasa..., hlm. 146-147. 
ini sesuai dengan penuturan Agus Riyanto yang menyatakan bahwa sebagai orang tua berharap dengan didukung berbagai fasilitas yang memadai di MIN 1 Kulon Progo diharapkan siswa dapat dengan mudah menguasai materi akhirnya nanti akan mendapat nilai tinggi dan ada persaingan nilai antar siswa. ${ }^{18}$ Sedangkan menurut Dwi Maryanti menuturkan harapannya agar menjadi anak yang cerdas, pandai dan pada akhirnya mendapatkan nilai yang baik. ${ }^{19}$ Hal yang sama juga disampaikan Nur Rohmah harapannya anak memiliki kecerdasan tinggi sehingga dengan mudah menguasai materi pelajaran yang pada akhirnya nanti akan mendapat nilai tinggi. ${ }^{20}$

Sementara itu kinerja madrasah terhadap peningkatan nilai siswa dapat ditunjukan melalui kegiatan mengadakan tambahan pelajaran (les) dan mengadakan pemantauan nilai siswa dengan hasil ulangan disampaikan kepada orang tua. Hal tersebut sesuai dengan penjelasan kepala madrasah. Untuk peningkatan nilai siswa dengan cara: :menambah waktu pembelajaran di luar jam wajib (berupa les), mengembalikan hasil pekerjaan kepada siswa agar siswa dan orang tua mengetahui hasil pencaian nilainya, mengetahui hasil yang telah dicapai maka akan mendorong siswa untuk terus maju dalam

${ }^{18}$ Wawancara dengan Bapak Agus Riyanto orang tua dari Ahmad Musthofa Habibulloh kelas IV A, tanggal 9 September 2018. ${ }^{19}$ Wawancara dengan Ibu Dwi Maryanti orang tua dari Abrisyam Arya Ramadhan kelas V A, 9 September 2018.

${ }^{20}$ Wawancara dengan Ibu Nur Rohmah orang tua dari Alya Hanafi kelas 1 A, 9 September 2018. 
mencapai tujuan, menambah buku pelajaran, buku penunjang dan sarana pembelajaran pada awal tahun pelajaran. ${ }^{21}$

Menurut teori Kotler, kepuasan pelanggan adalah tingkat perasaan seseorang setelah membandingkan kinerja (atau hasil) yang ia rasakan dibandingkan dengan harapannya. ${ }^{22}$ Berdasarkan uraian di atas dapat ditarik kesimpulan bahwa kinerja MIN 1 Kulonprogo dalam peningkatan nilai siswa meliputi; menambah jam pealajaran (les), lembar jawaban dikembalikan kepada orang tua siswa, dan penambahan buku pelajaran, buku penunjang dan sarana sudah sejalan dengan harapan orang tua siswa yang meliputi; siswa dapat dengan mudah menguasai materi akhirnya nanti akan mendapat nilai baik, ada persaingan nilai antar siswa, menjadi anak yang cerdas, pandai. Meskipun demikian dalam kegiatan ini perlu dilaksanakan dengan tertib dan terjadwal yang formal.

e. Kepuasan Orang Tua terhadap Prestasi Non Akademik

Harapan orang tua siswa terhadap prestasi non akademik yaitu siswa memiliki prestasi non akademik. Madrasah diharapkan selalu mengikuti berbagai even perlombaan baik yang diselenggarakan oleh masyarakat maupun pemerintah. ${ }^{23}$ Sementara itu, kinerja madrasah dalam meningkatkan prestasi non akademik dengan mengikuti lomba baik yang diselenggarakan oleh Dinas Pendidikan Pemuda dan Olah Raga

${ }^{21}$ Wawancara dengan kepala MIN 1 KulonProgo, Widodo, S.Pd.I, 13 September 2018.

${ }^{22}$ Tjiptono, Manajemen Jasa...., hlm. 146-147.

${ }^{23}$ Rangkuman wawancara dengan orang tua siswa, Agus Riyanto, Dwi Maryanti, dan Nur Rohmah, 9 September 2018. 
maupun yang diselenggarakan Kementerian Agama. Sebelum mengikuti lomba siswa diberikan pelatihan yang intensif dengan pelatih dari guru sendiri maupun dari eksternal madrasah. ${ }^{24}$

Menurut Kotler, kepuasan pelanggan adalah tingkat perasaan seseorang setelah membandingkan kinerja (atau hasil) yang ia rasakan dibandingkan dengan harapannya. ${ }^{25}$ Berdasarkan uraian di atas dapat ditarik kesimpulan bahwa kinerja MIN 1 Kulon Progo dalam meningkatkan prestasi non akademik siswa dengan cara mengikuti lomba, sebelum lomba diadakan pelatihan intensif dan mendapatkan kejuaraan dalam lomba sudah sejalan dengan harapan orang tua siswa yaitu siswa memiliki prestasi non akademik yang unggul, madrasah mengikuti berbagai event perlombaan untuk melatih mental siswa, dan siswa dapat meraih prestasi dalam setiap lomba.

f. Kepuasan Orang Tua terhadap Prestasi Akademik Siswa

Harapan orang tua siswa terhadap prestasi akademik yaitu siswa dalam menempuh ujian akhir dapat mendapatkan nilai yang baik, sehingga dapat masuk jenjang pendidikan yang lebih tinggi dapat diterima pada sekolah yang diinginkan. ${ }^{26}$ Sementara ini, kinerja madrasah dalam meningkatkan prestasi belajar siswa yaitu: ${ }^{27}$ mengadakan kegiatan tambahan pelajaran (les) mata pelajaran yang di uji Sekolah/Madrasah, mengadakan

\footnotetext{
${ }^{24}$ Wawancara dengan Kepala MIN 1 Kulon Progo, Widodo, S.Pd.I, 13 September 2018.

25 Tjiptono, Manajemen Jasa.

${ }^{26}$ Rangkuman wawancara dengan orang tua siswa, Agus Riyanto, Dwi Maryanti, dan Nur Rohmah, 9 September 2018.

27 Wawancara dengan Ibu Fitri Asmawati, S.Pd.I, Guru Kelas VI MIN 1 Kulon Progo, 13 September 2018.
} 
berbagai pendalaman materi (latihan ujian) mulai dari tingkat madrasah, tingkat kecamatan, dan kabupaten, mengadakan kegiatan motivasi ujian, menyelenggarakan doa bersama atau mujahaddah.

Dalam teori kepuasan pelanggan menururt Kotler, kepuasan pelanggan adalah tingkat perasaan seseorang setelah membandingkan kinerja (atau hasil) yang ia rasakan dibandingkan dengan harapannya. ${ }^{28}$ Berdasarkan uraian di atas dapat ditarik kesimpulan bahwa kinerja MIN 1 Kulon Progo dalam peningkatan prestasi siswa meliputi dengan hasil ujian madrasah yang tiap tahun belum mengalami peningkatan belum semuanya sejalan dengan harapan orang tua siswa yang meliputi; dalam pelaksanaan ujian siswa dilatih jujur dan mendapatkan nilai yang tinggi, lulusan MIN 1 Kulon Progo dapat masuk pada SMP sesuai yang diinginkan. Meskipun demikian orang tua juga tidak terlalu kecewa karena ternyata lulusan madrasah setelah masuk SMP mampu bersaing dengan siswa yang lain, hal ini berarti pelaksanaan ujian dilaksanakan dengan mengutamakan kejujuran siswa.

Sedangkan Engel, dkk mengungkapkan bahwa kepuasan pelanggan merupakan evaluasi purnabeli di mana alternatif yang dipilih sekurang-kurangnya memberikan hasil (outcame) sama atau melampaui harapan pelanggan, sedangkan ketidakpuasan timbul apabila hasil yang diperoleh tidak memenuhi harapan pelanggan. Kotler menandaskan bahwa kepuasan pelanggan adalah tingkat perasaan seseorang setelah

${ }^{28}$ Tjiptono, Manajemen Jasa..., hlm. 146-147. 
membandingkan kinerja (atau hasil) yang ia rasakan dibandingkan dengan harapannya. ${ }^{29}$

Dari uraian di atas dapat ditarik kesimpulan, kinerja madrasah dalam memenuhi kepuasan orang tua siswa yaitu orang tua siswa merasa puas dengan kinerja madrasah karena harapan-harapan orang tua sudah dapat terpenuhi, meskipun demikian masih ada sebagian harapan yang belum terpenuhi yaitu dalam peningkatan nilai ujian akhir madrasah sehingga kepala madrasah bersama stakeholder perlu untuk meningkatkan kinerja.

\section{Kebijakan Internal Madrasah}

Kepala sekolah memiliki kemampuan dalam pengelolaan administrasi yang bersifat pencatatan, penyusunan, dan pengarsipan dokumen seluruh program sekolah. Dalam hal ini kepala madrasah juga memiliki kemampuan dan wewenang dalam membuat kebijakan madrasah. Kebijakan internal madrasah di MIN 1 Kulon Progo dalam memenuhi kepuasan orang tua siswa yaitu:

a. Kebijakan Internal untuk Peningkatan Kualitas Ibadah Siswa

Kepala MIN 1 Kulon Progo mengambil kebijakan tentang peningkatan ibadah siswa meliputi: pertama, kegiatan shalat zuhur berjamaah. Shalat zuhur berjamaah dilakukan untuk mendidik siswa agar terbiasa melaksanakan shalat secara berjamaah. Selain itu, juga untuk menanamkan nilai dan pengetahuan siswa tentang pentingnya shalat berjamaah.

${ }^{29}$ Tjiptono, Manajemen Jasa..., hlm. 146-147. 
Sehingga siswa dapat menjalankan shalat berjamaah dengan benar.

Kedua, kegiatan shalat Dhuha. Pembiasaan shalat dhuha dilaksanakan untuk mendidik siswa agar terbiasa melaksanakan shalat dengan benar. Dengan shalat dhuha, dapat mendidik anak agar menjadi anak yang bertakwa kepada Allah SWT. Kegiatan shalat dhuha untuk kelas satu dan kelas dua dilaksanakan dengan dilafalkan keras dengan maksud untuk melatih siswa menghafal bacaan-bacaan dalam shalat. Madrasah mempunyai tujuan bahwa siswa madrasah kelas tiga harus sudah bisa melaksanakan shalat dengan benar. Kegiatan shalat dhuha juga untuk membiasakan siswa agar terbiasa melaksanakannya.

Ketiga, tadarus Al Qur'an dan hafalan Juz 'Amma. Madrasah mengembangkan kegiatan pemahaman Al-Qur'an dengan kegiatan tadarus setiap pagi sebelum proses pembelajaran dimulai. Dalam kegiatan ini, setiap siswa diwajibkan untuk membaca Al-Qur'an dengan pembagian surat yang dibaca sudah ditentukan.

Keempat, pembelajaran tahfidz madrasah. Program tahfidz ini adalah membangun motivasi warga madrasah gemar belajar dan membaca Al-Quran, meningkatkan religiusitas madrasah melalui hafalan Al-Quran, membumikan nilai-nilai AlQuran agar menjadi karakter dan budaya siswa madrasah, dan meningkatkan motivasi pembelajaran siswa melalui hafalan AlQuran.

Kelima, membaca dan hafalan asmaul husna. Salah satu pentingnya hakikat dan makna pendidikan bagi anak adalah 
penanaman akidah, keyakinan tentang adanya Allah swt. Keyakinan ini perlu ditanamkan sejak dini pada qolbu peserta didik. Agar siswa mempunyai keyakinan yang kuat, maka sejak duduk di madrasah dikembangkan sikap cinta kepada Allah swt. dengan membaca asmaul husna.

Kebijakan-kebijakan di atas sejalan dengan harapan orang tua terhadap peningkatan ibadah siswa yaitu: anak dapat melaksanakan ibadah dengan baik dan benar sesuai syariat agama Islam, beriman dan bertakwa dan menjadi anak yang sholehsholehah. ${ }^{30}$ Hal tersebut sesuai dengan pandangan Syafarudin yang menyatakan bahwa kebijakan dapat dipandang sebagai: (a) pedoman untuk bertindak, (b) pembatas perilaku, dan (c) bantuan bagi pengambil keputusan. Begitu pentingnya kebijakan dalam suatu organisasi karena itu dijadikan sebagai pedoman perilaku dalam berbagai aktivitas strategis untuk mencapai tujuan organisasi. ${ }^{31}$

Kebijakan untuk peningkatan ibadah siswa dituangkan dalam Surat Keputusan Kepala MIN 1 Kulon Progo Nomor 15 Tahun 2017 tentang Penyelenggaraan Kegiatan Pembiasaan peningkatan ibadah siswa tahun pelajaran 2017/2018, kebijakan ini mulai diterapkan pada awal tahun pelajaran 2017/2018 Dengan terbitnya surat keputusan tersebut di atas, artinya

${ }^{30}$ Rangkuman wawancara dengan orang tua siswa, Agus Riyanto, Dwi Maryanti, dan Nur Rohmah, 9 September 2018

31 Syafaruddin Syafaruddin, Efektifitas Kebijakan Pendidikan (Jakarta: Rineka Cipta, 2008), hlm. 78.

32 Dokumentasi SK Kepala MIN 1 Kulon Progo Nomor 15 Tahun 2017, tanggal 19 September 2018. 
kebijakan untuk meningkatkan ibadah siswa merupakan kebijakan internal kepala madrasah yang sudah formal.

Berdasarkan uraian di atas, disimpulkan bahwa bahwa kebijakan internal madrasah dalam meningkatkan ibadah siswa yaitu; kegiatan shalat Zuhur berjamaah, shalat dhuha, tadarus dan hafalan juz 'Amma, tahfidzul Qur'an serta membaca dan hafalan asmaul husna dapat memenuhi kepuasan orang tua siswa MIN 1 Kulon Progo.

b. Kebijakan dalam Meningkatkan Akhlak dan Kepribadian Siswa Untuk menjadikan siswa yang berperilaku muslim, Kepala MIN 1 Kulon Progo mengambil langkah kebijakan dengan cara menganjurkan warga madrasah dalam hal ini kepala madrasah, guru, pegawai dan siswa untuk selalu bersikap dan berperilaku sesuai dengan nilai-nilai yang terkandung dalam ajaran Islam antara lain: ${ }^{33}$ (1) selalu mengucapkan salam saat bertemu, lebih-lebih kepada siswa terhadap guru atau orang yang lebih tua, (2) berjabat tangan saat bertemu, bagi siswa dengan mencium tangan guru karena itu termasuk salah satu dalam pendidikan karakter, yang juga sudah dicanangkan oleh Bupati Kulon Progo berupa Program Pendidikan Karakter (PPK) yang wajib dilaksanakan di sekolah-sekolah, (3) berjabat tangan saat selesai upacara, (4) mengembangkan budaya senyum, salam, sapa

${ }^{33}$ Wawancara dengan kepala MIN 1 Kulon Progo, 13 September 2018. 
di lingkungan madrasah maupun di luar, (5) bertutur kata yang sopan, dengan bahasa Jawa setiap hari Sabtu. ${ }^{34}$

Kebijakan di atas sejalan dengan harapan orang tua terhadap peningkatan akhlak dan kepribadian siswa meliputi: anak memiliki akhlak terpuji, tata krama dalam pergaulan, menghormati orang tua, memiliki kepribadian yang baik, berlaku sopan. ${ }^{35}$ Hal tersebut sesuai dengan penjelasan Syafarudin bahwa kebijakan dapat dipandang sebagai: (a) pedoman untuk bertindak, (b) pembatas perilaku, dan (c) bantuan bagi pengambil keputusan. Kebijakan dalam suatu organisasi karena itu dijadikan sebagai pedoman perilaku dalam berbagai aktivitas strategis untuk mencapai tujuan organisasi. ${ }^{36}$ Berdasarkan uraian di atas, disimpulkan bahwa kebijakan peningkatan akhlak dan kepribadian siswa juga dapat memenuhi kepuasan orang tua siswa MIN 1 Kulon Progo.

c. Kebijakan dalam Meningkatkan Keterampilan Siswa

Untuk mengembangkan keterampilan siswa MIN 1 Kulon Progo mengembangkan kegiatan yang terprogram dalam kegiatan pengembangan diri (ekstrakurikuler). Kegiatan pengembangan diri tersebut adalah: pertama, kegiatan kepramukaan. Kepramukaan merupakan kegiatan kepanduan yang mendidik generasi muda agar memiliki keterampilan dan

34 Dokumentasi notula rapat MIN 1 Kulon Progo, diakses 15 September 2018.

35 Rangkuman wawancara dengan orang tua siswa, Agus Riyanto, Dwi Maryanti, dan Nur Rohmah, 9 September 2018.

${ }^{36}$ Syafaruddin, Efektifitas Kebijakan Pendidikan..., hlm. 78. 
kecakapan hidup. Kepramukaan juga untuk mendidik kedisiplinan siswa.

Kedua, kegiatan qosidah. Kegiatan Qosidah menjadi salah satu ikon madrasah, yang sudah dilaksanakan sejak tahun 2002, qosidah MIN 1 Kulon Progo bernama qosidah "AlJamilah" yang pesertanya siswa perempuan. Dalam kegiatan ekstra kurikuler qosidah ini siswa dilatih untuk dapat memainkan berbagai alat musik dan bermain vokal. Kegiatan ini juga melatih siswa untuk memiliki rasa percaya diri sehingga terbiasa tampil di depan umum dalam berbagai pentas.

Ketiga, kegiatan musik. Keterampilan dalam memainkan alat musik merupakan salah satu tujuan diselenggarakan ekstrakurikuler ini. Sebelum siswa mengikuti ekstra kurikuler qosidah, siswa dikenalkan dulu dengan musik, termasuk bagaimana memainkannya. Dalam kegiatan tersebut, siswa tidak hanya dikenalkan musik qosidah tetapi musik pada umumnya termasuk di dalamnya main piano.

Keempat, kegiatan hadroh. Hadroh merupakan salah satu kesenian yang bernafaskan Islami yang dikembangkan dalam kegiatan ekstrakurikuler di MIN 1 Kulon Progo, dalam kegiatan ini diharapkan para siswa untuk dapat mencintai musik Islami dan senang melantunkan sholawat nabi dengan diiringi lantunan musik.

Kelima, kegiatan qiro'ah. Qiro'ah merupakan salah satu kegiatan pengembangan diri yang dilaksanakan dalam membekali siswa dalam bidang baca seni Al-Quran di MIN 1 Kulon Progo. Kegiatan qiroah menjadi ekstra pilihan. 
Keenam $_{s}$ kegiatan drumband. Kegiatan ini menjadi salah satu ekstra pilihan bagi siswa madrasah yang diikuti oleh siswa kelas 3 sampai 5. Korp drumband MIN 1 Kulon Progo sudah tampil dalam berbagai lomba dan mendapat kejuaraan.

Ketujuh, kegiatan kempo. Kegiatan Kempo merupakan salah satu kegiatan yang diikuti secara sukarela oleh para siswa. Kegaitan ini di sampimg untuk ketahanan fisik juga untuk mengembangkan bakat siswa dalam bela diri. Dalam kempo ini siswa juga sering mengikuti berbagai pertandingan.

Kebijakan untuk peningkatan prestasi keterampilan siswa di atas dituangkan dalam Surat Keputusan Kepala MIN Sindutan (MIN 1 Kulon Progo) Nomor 14.1 Tahun 2015 tentang Penyelenggaraan Kegiatan Ekstrakuriler dan pembimbing ekstrakurikuler tahun pelajaran 2015/2016. ${ }^{37}$ Kebijakan ini mulai diterapkan pada awal tahun pelajaran 2015/2016.

Kebijakan di atas, sejalan dengan harapan orang tua terhadap peningkatan keterampilan siswa meliputi: anak memiliki bemacam-macam keterampilan yang dapat menjadi bekal hidupnya di masyarakat, termasuk baca seni Al-Qur'an. ${ }^{38}$ Kebijakan-kebijakan di atas sesuai dengan pendapat Syafarudin bahwa kebijakan dapat dipandang sebagai: (1) pedoman untuk bertindak, (2) pembatas perilaku, dan (3) bantuan bagi pengambil keputusan. Kebijakan dalam suatu organisasi dijadikan sebagai pedoman perilaku dalam berbagai aktifitas strategis untuk

${ }^{37}$ Dokumentasi SK Kepala MIN Sindutan Nomor 14.1 Tahun 2015, tanggal 19 September 2018.

${ }^{38}$ Rangkuman wawancara dengan orang tua siswa, Agus Riyanto, Dwi Maryanti, dan Nur Rohmah, 9 September 2018. 
mencapai tujuan organisasi. ${ }^{39}$ Berdasarkan uraian di atas dapat disimpulkan bahwa kebijakan internal madrasah dalam meningkatkan keterampilan siswa yaitu kegiatan kepramukaan qosidah, musik, hadroh, qiroah, drumband dan kempo dapat memenuhi kepuasan orang tua siswa MIN 1 Kulon Progo.

d. Kebijakan dalam Meningkatkan Nilai Ulangan Siswa

Belajar adalah suatu proses yang menimbulkan terjadinya suatu perubahan tingkah laku atau kecakapan. Siswa akan berhasil dalam pembelajarannya apabila berhasil dalam menyerap kurikulum atau meteri pelajaran yang disampaikan oleh guru dengan dibuktikan keberhasilannya adalah nilai yang baik. Dalam rangka meningkatkan pencapaian nilai siswa maka kepala madrasah mengambil kebijakan internal madrasah yaitu: (1) menambah waktu pembelajaran di luar jam wajib sekolah. (di luar jam pembelajaran), waktu kegiatan diatur atas kesepakatan guru kelas dengan Perkumpulan Wali Murid (PWM); (2) melengkapi buku penunjang dan sarana prasarana pendidikan; (3) mengembalikan hasil pekerjaan kepada siswa agar siswa dan orang tua mengetahui hasil pencaian nilainya, mengetahui hasil yang telah dicapai maka akan mendorong siswa untuk terus maju dalam mencapai tujuan. ${ }^{40}$

Kebijakan di atas sejalan dengan harapan orang tua terhadap peningkatan nilai siswa meliputi: siswa dapat dengan mudah menguasai materi, akhirnya nanti akan mendapat nilai

${ }^{39}$ Syafaruddin, Efektifitas Kebijakan Pendidikan..., hlm. 78. ${ }^{40}$ Wawancara dengan Kepala MIN 1 Kulon Progo, 13 September 2018 
baik dan ada persaingan nilai antar siswa, menjadi anak yang cerdas, pandai. ${ }^{41}$ Kebijakan di atas sesuai dengan pandangan Syafarudin bahwa kebijakan dapat dipandang sebagai: (1) pedoman untuk bertindak, (2) pembatas perilaku, dan (3) bantuan bagi pengambil keputusan. Kebijakan dalam suatu organisasi dijadikan sebagai pedoman perilaku dalam berbagai aktifitas strategis untuk mencapai tujuan organisasi. ${ }^{42}$

Berdasarkan uraian di atas, dapat disimpulkan bahwa kebijakan internal madrasah dalam meningkatkan nilai yaitu kegiatan tambahan jam pelajaran, penambahan buku dan sarana prasarana, serta pengembalian hasil ulangan siswa dapat memenuhi kepuasan orang tua siswa MIN 1 Kulon Progo. Kebijakan ini baru sebatas hasil rapat yang belum dituangkan dalam surat keputusan sehingga masih menjadi kebijakan non formal.

e. Kebijakan dalam Meningkatkan Prestasi Non Akademik

Kebijakan kepala MIN 1 Kulon Progo dalam peningkatan prestasi non akademik adalah mengikuti berbagai lomba dan sering memperoleh kejuaraan. Untuk mempertahankan prestasi non akademik yang diperoleh maka madrasah melakukan kebijakan: (1) melakukan pelatihan yang intensif sebelum mengikuti lomba dengan cara menambah frekuensi latihan; (2) melengkapi berbagai sarana dan prasarana yang dibutuhkan agar bisa optimal; (3) mendatangkan

${ }^{41}$ Rangkuman wawancara dengan orang tua siswa, Agus Riyanto, Dwi Maryanti, dan Nur Rohmah, 9 September 2018.

${ }^{42}$ Syafaruddin, Efektifitas Kebijakan Pendidikan..., hlm. 78. 
pembimbing yang memiliki kompetensi dari luar madrasah. Kebijakan ini dilaksanakan setiap akan mengikuti lomba. ${ }^{43}$

Kebijakan peningkatan prestasi non akademik di atas sejalan dengan harapan orang tua siswa yaitu siswa memiliki prestasi non akademik yang unggul, madrasah mengikuti berbagai event perlombaan untuk melatih mental siswa, dan siswa dapat meraih prestasi dalam setiap lomba. Kebijakan di atas sesuai dengan penjelasan Syafarudin bahwa kebijakan dapat dipandang sebagai: (a) pedoman untuk bertindak, (b) pembatas perilaku, dan (c) bantuan bagi pengambil keputusan. Kebijakan dalam suatu organisasi dijadikan sebagai pedoman perilaku dalam berbagai aktivitas strategis untuk mencapai tujuan organisasi. $^{44}$

Berdasarkan uraian di atas dapat disimpulkan bahwa kebijakan internal madrasah dalam meningkatkan prestasi non akademik yaitu melaksanakan pelatihan intensif sebelum lomba, melengkapi sarana prasarana dan mendatangkan pelatih dari luar madrasah dapat memenuhi kepuasan orang tua siswa MIN 1 Kulon Progo. Meskipun demikian, kebijakan ini baru sebatas hasil rapat yang masih ada yang belum dituangkan dalam surat keputusan sehingga masih menjadi kebijakan non formal.

f. Kebijakan dalam Meningkatkan Prestasi Akademik

Mendapatkan nilai ujian yang baik menjadi kebanggaan MIN 1 Kulon Progo maupun bagi siswa dan orang tua. Kegiatan

\footnotetext{
43 Wawancara dengan kepala MIN 1 Kulon Progo, 13 September 2018

.${ }^{44}$ Syafaruddin, Efektifitas Kebijakan Pendidikan..., hlm. 78.
} 
yang dilakukan MIN 1 Kulon Progo untuk meningkatkan prestasi akademik yaitu: ${ }^{45}$ (1) mengadakan kegiatan tambahan pelajaran (les) mata pelajaran yang di Ujian Sekolah/Madrasah (U S/M) kepada calon peserta ujian / kelas VI; (2) mengadakan kegiatan pendalaman materi (latihan ujian) dimulai dari latihan ujian tingkat madrasah, kecamatan dan kabupaten; (3) mengadakan kegiatan motivasi ujian bagi peserta didik kelas VI. Dengan kegiatan ini, dimaksudkan agar siswa siap mengikuti ujian, percaya diri dan optimis untuk mendapatkan nilai yang maksimal. Berikutnya, (4) doa bersama atau mujahaddah merupakan kegiatan rutin yang dilaksanakan MIN 1 Kulon Progo menjelang pelaksanaan ujian. Kegiatan ini untuk mendekatkan diri kepada Allah swt. serta memohon agar pelaksanaan ujian dapat sukses terlaksana dan sukses hasil.

Hal tersebut diperkuat dengan kebijakan kepala MIN 1 Kulon Progo. Kebijakan untuk peningkatan prestasi akademik / nilai ujian dituangkan dalam Surat Keputusan Kepala MIN 1 Kulon Progo Nomor 03.A Tahun 2018 tentang Pembentukan Tim Sukses Ujian Tahun Pelajaran 2017/2018. ${ }^{46}$ Pembentukan tim sukses ujian dibentuk setiap tahun menjelang ujian. Kebijakan di atas sejalan dengan harapan orang tua terhadap peningkatan prestasi akademik siswa meliputi; dalam pelaksanaan ujian siswa

Wawancara dengan Ibu Fitri Asmawati, S.Pd.I, Guru Kelas VI MIN 1 Kulon Progo, 13 September 2018.

${ }^{46}$ Dokumentasi SK Kepala MIN 1 Kulon Progo Nomor 03.A Tahun 2018, tanggal 19 September 2018. 
dilatih jujur dan mendapatkan nilai yang tinggi, lulusan. MIN 1 Kulon Progo dapat masuk pada SMP sesuai yang diinginkan. ${ }^{47}$

Kebijakan di atas sesuai dengan teori Syafarudin bahwa kebijakan dapat dipandang sebagai: (a) pedoman untuk bertindak, (b) pembatas perilaku, dan (c) bantuan bagi pengambil keputusan. Kebijakan dalam suatu organisasi dijadikan sebagai pedoman perilaku dalam berbagai aktivitas strategis untuk mencapai tujuan organisasi. $^{48}$

Berdasarkan uraian di atas, dapat disimpulkan bahwa kebijakan internal madrasah dalam meningkatkan prestasi akademik siswa yaitu dibentuknya tim sukses ujian madrasah. Kemudian tim melakukan kegiatan les, pendalaman materi, motivasi dan mujahadah dapat memenuhi kepuasan orang tua siswa MIN 1 Kulon Progo. Dari uraian di atas, kebijakan internal kepala MIN 1 Kulon Porgo dapat diklasifikasikan menjadi dua yaitu pertama kebijakan formal internal madrasah yang sudah dibuat menjadi surat keputusan meliputi; kebijakan penyelenggaraan kegiatan pembiasaan madrasah, kebijakan penyelenggaraan kegiatan ekstrakurikuler, kebijakan tim pembimbing lomba, dan kebijakan pembentukan tim sukses ujian. Kedua kebijakan non formal madrasah karena kebijakan itu belum dibuat surat keputusannya masih sebatas hasil rapat dalam bentuk notula, namun kebijakan itu sudah dilaksanakan yang meliputi; kebijakan meningkatkan akhlak dan kepribadian

${ }^{47}$ Rangkuman wawancara dengan orang tua siswa, Agus Riyanto, Dwi Maryanti, dan Nur Rohmah, 9 September 2018.

${ }^{48}$ Syafaruddin, Efektifitas Kebijakan Pendidikan...., hlm. 78. 
dengan budaya senyum, salam dan sapa, bertutur kata sopan, berbahasa Jawa setiap hari sabtu, kebijakan meningkatkan nilai dengan les.

Hal tersebut sesuai dengan teori Riant Nugroho bahwa kebijakan dalam bentuk legal-formal untuk dijadikan sebagai dasar hukum (legal framework) yang bersifat formal, khususnya bagi pelaksanaan kebijakan. ${ }^{49}$ Di samping itu kebijakan publik dirumuskan melalui interaksi intensif di antara para pemangku kepentingan atau konstituen (stakeholders), di mana pada akhirnya kesepakatan di antara mereka yang ditetapkan sebagai kebijakan publik. ${ }^{50}$

Adapun respon dari stakeholder terhadap kebijakan internal madrasah dalam memenuhi kepuasan orang tua yang diterapkan oleh kepala MIN 1 Kulon Progo yaitu: pertama, pandangan positif masyarakat terhadap madrasah. Dengan adanya berbagai kebijakan internal madrasah sehingga mutu madrasah meningkat, madrasah mengalami kemajuan baik dalam bidang akademik maupun non akademik, seperti penuturan kepala madrasah sebagai berikut: "Masyarakat dan pemerintah semakin percaya, dengan adanya berbagai kebijakan internal madrasah maka mutu madrasah meningkat, madrasah mengalami kemajuan baik dalam bidang akademik maupun non akademik." ${ }^{51}$ Kedua, peningkatan dalam penerimaan peserta didik baru. Orang

49 Riant Nugroho, Kebijakan Pendidikan Yang Unggul, 2nd ed. (Yogyakarta: Pustaka Pelajar, 2013), hlm. 168.

${ }^{50}$ Nugroho, hlm. 91.

${ }^{51}$ Wawancara dengan kepala MIN 1 Kulon Progo, Widodo, S.Pd.I, 13 September 2018. 
tua mempunyai banyak harapan kepada madrasah, Kepala madrasah sebagai leader di madrasah memiliki peranan dalam memenuhi harapan orang tua. Hasil kinerja madrasah sudah mampu memenuhi kepuasan orang tua wali siswa. Kepercayaan masyarakat kepada madrasah mulai tumbuh lagi.

\section{SIMPULAN}

Penelitian ini menemukan bahwa terdapat kepuasan orang tua terhadap layanan pendidikan di MIN 1 Kulon Progo. Hal ini ditunjukan melalui keselarasan antara harapan orang tua siswa dengan kinerja madrasah. Harapan orang tua meliputi; anak dapat melaksanakan ibadah dengan baik dan benar sesuai syariat agama Islam, dapat melaksanakan shalat dengan benar, dapat membaca Qur'an, dan menjadi anak yang bertakwa, anak memiliki akhlak terpuji, memiliki kepribadian yang baik, memiliki keterampilan yang dapat menjadi bekal hidupnya di masyarakat, mendapat nilai baik, menjadi anak yang pandai, siswa memiliki prestasi non akademik yang unggul sehingga dapat meraih prestasi dalam setiap lomba, dan mendapatkan nilai ujian yang tinggi. Sementara itu, kinerja madrasah untuk memenuhi kepuasan orang tua siswa meliputi; dilaksanakannya kegiatan shalat Zuhur berjamaah, hafalan juz 'Amma dan tadarus, shalat dhuha, tahfidzul Qur'an, hafalan asmaul husna, pengembangan budaya madrasah senyum, salam sapa serta jabat tangan, kegiatan les untuk semua kelas, diselenggarakan kegiatan ekstrakurikuler kepramukaan, drumband, qosidah, musik, dan qiroah. Diadakan pelatihan intensif saat mau lomba, untuk calon peserta ujian diadakan les kelas VI dan pendalaman materi. 
Kebijakan internal madrasah untuk memenuhi kepuasan orang tua siswa meliputi: (1) Kebijakan peningkatan kualitas ibadah siswa yang terdiri dari; kegiatan shalat zuhur berjamaah, hafalan juz 'Amma dan tadarus, sholat duha, tahfidzul Qur'an, hafalan asmaul husna; (2) Kebijakan meningkatkan akhlak dan kepribadian siswa dengan pengembangan budaya madrasah senyum, salam, sapa serta jabat tangan; (3) Kebijakan peningkatkan nilai ulangan siswa dengan kegiatan les untuk semua kelas; (4) Kebijakan dalam peningkatkan ketrampilan siswa dengan diselenggarakan kegiatan ekstrakurikuler kepramukaan, drumband, qosidah, musik, dan qiroah; (5) Kebijakan dalam peningkatan prestasi non akademik siswa dengan diadakan pelatihan intensif saat mau lomba; dan (6) Kebijakan untuk peningkatkan prestasi akademik siswa dengan kegiatan les kelas VI dan pendalaman materi, motivasi calon peserta ujian dan doa bersama sebelum ujian.

\section{E. DAFTAR PUSTAKA}

Dokumentasi notula rapat MIN 1 Kulon Progo, diakses 15 September 2018 Dokumentasi SK Kepala MIN Sindutan Nomor 14.1 Tahun 2015, tanggal 19 September 2018.

Dokumentasi SK Kepala MIN 1 Kulon Progo Nomor 15 Tahun 2017, tanggal 19 September 2018.

Mufidah, Nurul. "Peran Manajer Kepala MIN Jejeran Bantul Dalam Implementasi Manajemen Berbasis Madrasah." Jurnal Manajemen Pendidikan Islam 2, no. 1 (2007).

Mulyasa, Mulyasa. Pedoman Manajemen Berbasis Madrasah. Jakarta: Direktorat Jenderal Kelembagaan Agama Islam DEPAG RI, 2004.

Nugroho, Riant. Kebijakan Pendidikan Yang Unggul. 2nd ed. Yogyakarta: Pustaka Pelajar, 2013.

Progo, Pemerintah Daerah Kulon. Buku Pedoman Pelaksanaan Pendidikan Karakter Kabupaten Kulon Progo Jenjang SD/MI, 2017. 
Purwanto, Ngalim. Psikologi Pendidikan. Bandung: PT. Remaja Rosdakarya, 2007.

Sugiyono, Sugiyono. Metode Penelitian Pendidikan: Pendekatan Kuantitatif, Kualitatif Dan R\&D. Bandung: Alfabeta, 2010. Syafaruddin, Syafaruddin. Efektifitas Kebijakan Pendidikan. Jakarta: Rineka Cipta, 2008.

Tjiptono, Fandy. Manajemen Jasa. 4th ed. Yogyakarta: Andi Offset, 2006.

Tjiptono, Fandy, and Anastasia Diana. Total Quality Management. Yogyakarta: Andi Offset, 2003.

Wawancara dengan Bapak Agus Riyanto orang tua dari Ahmad Musthofa Habibulloh kelas IV A, tanggal 9 September 2018. Wawancara dengan Ibu Fitri Asmawati, S.Pd.I, Guru Kelas VI MIN 1 Kulon Progo, 13 September 2018.

Wawancara dengan Ibu Dwi Maryanti orang tua dari Abrisyam Arya Ramadhan kelas V A, 9 September 2018.

Wawancara dengan Ibu Nur Rohmah orang tua dari Alya Hanafi kelas 1 A, 9 September 2018.

Wawancara dengan Kepala MIN 1 Kulon Progo, Widodo, S.Pd.I, 13 September 2018.

Wawancara dengan Widodo, S.Pd.I kepala MIN 1 Kulon Progo, dan dokumentasi MIN 1 Kulon Progo, pada tanggal 15 Agustus 2018.

Zakiah, Qiqi Yuliati, and A Rusdiana. Pendidikan Nilai Kajian Teori Dan Praktik Di Sekolah. Bandung: Pustaka Setia, 2014. 